\title{
Effect of industrial wood particle size on mechanical properties of wood-polyvinyl chloride composites
}

\author{
Marek Kociszewski • Cezary Gozdecki • \\ Arnold Wilczyński · Stanisław Zajchowski · \\ Jacek Mirowski
}

Received: 27 October 2010 / Published online: 19 February 2011

(C) The Author(s) 2011. This article is published with open access at Springerlink.com

\begin{abstract}
Wood-polyvinyl chloride (PVC) composites were prepared using industrial wood particles used for manufacturing three-layer particleboards. The effect of particle size $(0.25-0.5,0.5-1,1-2$, and $2-4 \mathrm{~mm})$ on the mechanical properties of the composites was investigated. The effect of cross-section size $\left(4 \times 10,6 \times 15\right.$ and $\left.8 \times 20 \mathrm{~mm}^{2}\right)$ of composite pieces made by an injection moulding method was also studied. Both the particle size and specimen crosssection area significantly influenced these properties. The tensile and flexural properties as well as the impact strength in general increased with increasing particle size, and decreased with increasing cross-section size.
\end{abstract}

\section{Einfluss von industrieüblichen Holzspanabmessungen auf die mechanischen Eigenschaften von Holz-PVC-Verbundwerkstoffen}

Zusammenfassung Holz-PVC-Verbundwerkstoffe wurden unter Verwendung industrieüblicher Holzspäne, wie sie zur Herstellung von dreischichtigen Spanplatten eingesetzt werden, hergestellt. Der Einfluss der Spangröße $(0,25-0,5$, 0,5-1, 1-2 und 2-4 mm) auf die mechanischen Eigenschaften der Verbundwerkstoffe sowie der Einfluss der Querschnittsgröße $\left(4 \times 10,6 \times 15\right.$ and $\left.8 \times 20 \mathrm{~mm}^{2}\right)$ der mittels Spritzgusstechnik hergestellten Verbundwerkstoffe wurde

M. Kociszewski · C. Gozdecki · A. Wilczyński (凶) Institute of Technology, Kazimierz Wielki University, ul. Chodkiewicza 30, 85-064 Bydgoszcz, Poland e-mail:wilczar@ukw.edu.pl

S. Zajchowski · J. Mirowski

Faculty of Chemical Technology and Engineering, University

of Technology and Life Sciences in Bydgoszcz,

ul. Ks. Kordeckiego 20, 85-225 Bydgoszcz, Poland untersucht. Sowohl die Spangröße als auch die Querschnittsabmessungen der Prüfkörper hatten einen Einfluss auf diese Eigenschaften. Die Zug- und Biegeeigenschaften sowie die Schlagbiegefestigkeit nahmen generell mit zunehmender Spangröße zu und mit zunehmender Querschnittsgröße $\mathrm{ab}$.

\section{Introduction}

Mechanical properties of wood plastic composites (WPCs) generally depend on the properties of their components and the ratio of these components. One of the factors affecting properties of a wood component is wood particle size. The effect of this factor on WPC mechanical properties was mainly evaluated for typical WPCs containing small wood particles (wood flour) or short wood fibres. WPCs with polypropylene (PP) (Zaini et al. 1996; Lee et al. 2001; Stark and Rowlands 2003; Khalil et al. 2006; Salemane and Luyt 2006; Kumari et al. 2007; Cheng et al. 2009; Pan et al. 2009) and high density polyethylene (HDPE) (Cui et al. 2008; Migneault et al. 2008, 2009; Bouafif et al. 2009) as the matrix were primarily studied. Results of some studies have shown that the effect of wood particle size on WPC mechanical properties was considerable, whereas others revealed that this effect was slight. For most tested WPCs an increase in wood particle size resulted in an increase in WPC mechanical properties, but in some cases there was a reverse tendency. The divergence of the results of these studies is difficult to interpret. It is due to many factors, mainly such as thermoplastic type, wood content, wood particle geometry, coupling agent type and content, and processing method. It can be concluded that the effect of wood particle size on WPC mechanical properties is not sufficiently clear. 
Polyvinyl chloride (PVC) is increasingly being used as a matrix of WPC, in particular by manufacturers of windows and deck profiles. This composite has well enough mechanical properties and high moisture, fungi and UV radiation resistance. Furthermore, it is relatively inexpensive and allows for multiple processing. Recycled PVC waste from pipes, windows and sidings can be successfully used to produce wood-PVC composites. Mechanical properties of WPCs with PVC as the matrix have seldom been studied (Bledzki et al. 1998; Takatani et al. 2000; $\mathrm{Xu}$ et al. 2008) compared to WPCs with PP and HDPE. The effect of wood or natural fibre content was mainly considered. Only Takatani et al. (2000) evaluated the effect of wood particle size for WPCs with softwood flour and steam exploded beech flour using two sizes of wood particle: 0.125 and $0.841 \mathrm{~mm}$. They found that the smaller particles gave better WPC flexural strength when softwood flour was the wooden component, and worse when a mix of softwood and steam-exploded beech flour was such a component.

Large-sized wood particles are seldom used as filler in WPCs, especially for the fabrication of WPCs by injection moulding. However, industrial wood particles with long length and a high length-to-thickness ratio were found to be useful for producing wood-PP (Bledzki and Faruk 2003; Gozdecki et al. 2006; Wilczyński et al. 2008) and woodHDPE (Chen et al. 2006) composites. Using these particles improves the WPC mechanical properties, compared with typical WPC with wood flour.

The continual increase in the use of WPCs results in the need to create WPCs with particular properties. Such can be WPCs with large-sized wood particles. In this study, industrial wood particles used for manufacturing the face and core layers of particleboards were employed to make wood-PVC composites by an injection moulding method. The aim of the study was to assess the effect of particle size on the mechanical properties of these composites. The use of large-sized particles makes the WPCs more heterogeneous, therefore it was decided to consider also the size of cross-section of injection moulded pieces.

\section{Materials and methods}

\subsection{Materials}

The PVC used in this study was POLANVIL S-58 obtained from Anwil S.A. (Poland). Its bulk density was $0.595 \mathrm{~g} / \mathrm{cm}^{3}$.

Industrial softwood particles used for manufacturing three-layer particleboards, fine particles for face layers and coarse particles for the core layer, were employed as raw wood material. They were supplied by Kronospan Szczecinek (Poland). Their fraction analysis is shown in Table 1 . The particles were screened by an analytical sieve
Table 1 Fraction analysis (\%) per weight of industrial wood particles Tab. 1 Siebanalyse in Masseprozent industrieüblicher Holzspäne

\begin{tabular}{|c|c|c|c|}
\hline \multicolumn{2}{|l|}{ Fine particle } & \multicolumn{2}{|l|}{ Coarse particle } \\
\hline $\begin{array}{l}\text { Screen hole size } \\
\text { range }(\mathrm{mm})\end{array}$ & $\begin{array}{l}\text { Content } \\
(\%)\end{array}$ & $\begin{array}{l}\text { Screen hole size } \\
\text { range }(\mathrm{mm})\end{array}$ & $\begin{array}{l}\text { Content } \\
(\%)\end{array}$ \\
\hline$<0.212$ & 11.5 & $<0.5$ & 1.9 \\
\hline $0.212-03$ & 9.2 & $0.5-1.0$ & 8.5 \\
\hline $0.3-0.4$ & 15.5 & $1.0-1.4$ & 11.3 \\
\hline $0.4-0.6$ & 20.9 & $1.4-2.0$ & 28.9 \\
\hline $0.6-1.0$ & 39.5 & $2.0-4.0$ & 42.9 \\
\hline $1.0-1.25$ & 3.2 & $4.0-6.3$ & 5.8 \\
\hline$>1.25$ & 0.2 & $>6.3$ & 0.7 \\
\hline
\end{tabular}
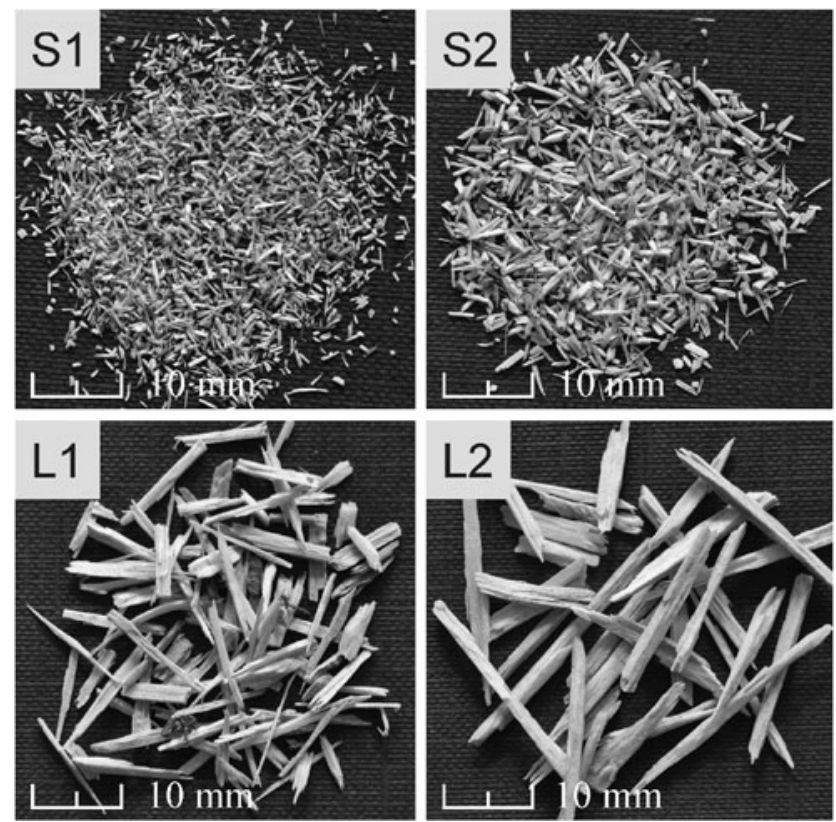

Fig. 1 Screened wood particles of S1, S2, L1 and L2 sizes Abb. 1 Gesiebte Holzspäne der Größe S1, S2, L1 und L2

shaker using sieves of $5,10,18,35$ and 60 mesh to obtain four particle sizes: (1) very small, S1, 0.25-0.5 mm; (2) small, S2, 0.5-1 mm; (3) large L1, 1-2 mm; and (4) very large L2, 2-4 $\mathrm{mm}$. The screened particles are shown in Fig. 1. Dimensions were measured for 200 randomly selected particles of each size, and length-to-thickness and width-to-thickness ratios were calculated to obtain particle geometric characteristics. Particle bulk density was also determined. Mean values of these parameters are listed in Table 2 .

\subsection{Sample preparation}

All the particles were dried at $80^{\circ} \mathrm{C}$ in an air-circulation oven for 24 hours before mixing in order to achieve a moisture content of less than $3 \%$. Next the particles were mixed with 
Table 2 Length, length/thickness and width/thickness ratios, and bulk density of wood particles

Tab. 2 Länge, Verhältnis von Länge zu Dicke und von Breite zu Dicke sowie Schüttdichte der Holzspäne

\begin{tabular}{lrlll}
\hline & $\begin{array}{l}\text { Length } \\
(\mathrm{mm})\end{array}$ & Length/thickness & Width/thickness & $\begin{array}{l}\text { Bulk density } \\
\left(\mathrm{g} / \mathrm{cm}^{3}\right)\end{array}$ \\
\hline S1 & $1.9(0.8)$ & $14.9(3.2)$ & $2.4(0.7)$ & 0.201 \\
S2 & $3.9(1.4)$ & $16.3(4.1)$ & $2.5(0.9)$ & 0.192 \\
L1 & $12.2(6.0)$ & $20.2(6.1)$ & $2.6(1.2)$ & 0.162 \\
L2 & $20.2(6.9)$ & $21.4(6.3)$ & $2.8(1.1)$ & 0.150 \\
\hline
\end{tabular}

Standard deviations in parentheses

PVC at $40 \%$ by weight. Test specimens were made by injection moulding using a screw injection moulding machine. The temperature profile was 140,175 and $180^{\circ} \mathrm{C}$. The injection pressure time, hold pressure time and cooling time were 3,6 and $40 \mathrm{~s}$, respectively. To minimize mechanical degradation of particles during moulding, the diameter of the injection die was enlarged to $4.5 \mathrm{~mm}$, and the diameter of the sprue bush to $8 \mathrm{~mm}$. The cross section of the runner and the gate was $10 \times 10 \mathrm{~mm}^{2}$ and $6 \times 6 \mathrm{~mm}^{2}$, respectively.

For determining the effect of cross-section size of injection moulded pieces, three cross-section areas were assumed: (1) $4 \times 10 \mathrm{~mm}^{2}$; (2) $6 \times 15 \mathrm{~mm}^{2}$; and (3) $8 \times$ $20 \mathrm{~mm}^{2}$. Specimens with these three cross-section sizes were made. Dimensions of those of $4 \times 10 \mathrm{~mm}^{2}$ crosssection were according to EN ISO 527, and dimensions of those of $6 \times 15 \mathrm{~mm}^{2}$ and $8 \times 20 \mathrm{~mm}^{2}$ cross-sections were adequately larger. After processing the specimens were stored in controlled conditions $\left(50 \%\right.$ relative humidity and $20^{\circ} \mathrm{C}$ ) for two weeks prior to testing.

\subsection{Methods of testing}

The mechanical properties of the obtained WPCs were evaluated according to standard procedures. Tensile and flexural properties were determined according to EN ISO 527 and EN ISO 178, respectively, using an Instron 3367 machine. Cross-head speed was $2 \mathrm{~mm}$ per min. Unnotched Charpy impact strength tests were conducted according to EN ISO 179 with PSd 50/15 impact test device. Ten replicates were run for each test. All tests were performed at room temperature $\left(20^{\circ} \mathrm{C}\right)$ and at constant relative humidity $(50 \%)$.

\section{Results and discussion}

\subsection{ANOVA analysis}

Mean values of the tensile modulus and strength, flexural modulus and strength, and impact strength of tested

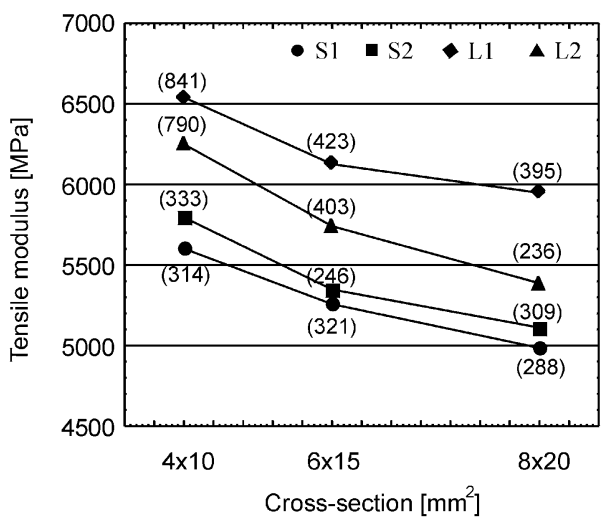

Fig. 2 Effect of specimen cross-section size on tensile modulus of WPC with different sizes of wood particles (standard deviations in parentheses)

Abb. 2 Einfluss der Querschnittsgröße der Prüfkörper und der Holzspangröße auf den Zugelastizitätsmodul von WPCs (Standardabweichung in Klammern)

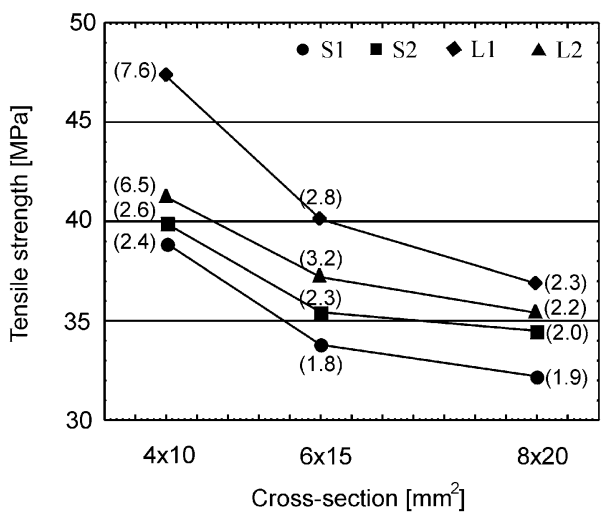

Fig. 3 Effect of specimen cross-section size on tensile strength of WPC with different sizes of wood particles (standard deviations in parentheses)

Abb. 3 Einfluss der Querschnittsgröße der Prüfkörper und der Holzspangröße auf die Zugfestigkeit von WPCs (Standardabweichung in Klammern)

WPCs are given in Figs. 2-6. Two-way analysis of variance (ANOVA) was conducted to determine the significance of the effects of particle size and cross-section size on the WPC mechanical properties (Table 3). Results of this analysis show that all mechanical properties vary significantly with particle size and specimen cross-section size. The interaction between these two variables is significant only for the flexural strength.

\subsection{Effect of particle size}

Specimens of different cross-section size and the same wood particle size were included in one group. The mean values of mechanical properties for these groups are presented in Table 4. Tukey's test was applied to evaluate the statistical 


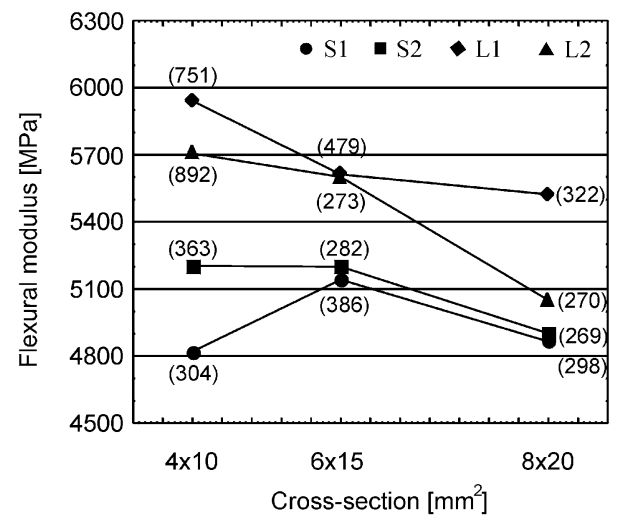

Fig. 4 Effect of specimen cross-section size on flexural modulus of WPC with different sizes of wood particles (standard deviations in parentheses)

Abb. 4 Einfluss der Querschnittsgröße der Prüfkörper und der Holzspangröße auf den Biegeelastizitätsmodul von WPCs (Standardabweichung in Klammern)

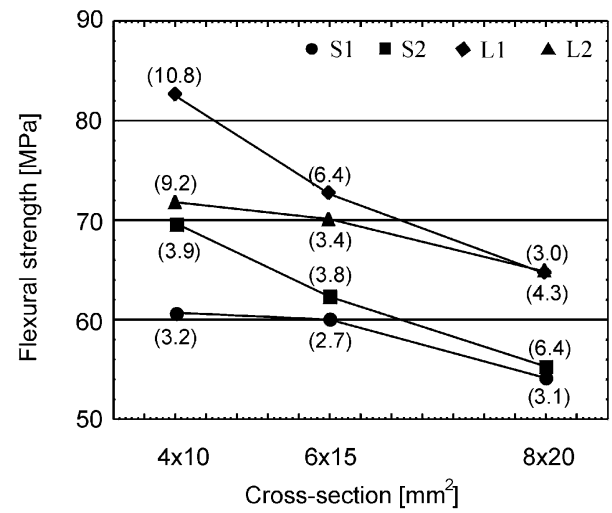

Fig. 5 Effect of specimen cross-section size on flexural strength of WPC with different sizes of wood particles (standard deviations in parentheses)

Abb. 5 Einfluss der Querschnittsgröße der Prüfkörper und der Holzspangröße auf die Biegefestigkeit von WPCs (Standardabweichung in Klammern) significance between mean values of mechanical properties of WPCs with different particle sizes. Values with the same letter for given property are not significantly different at the $5 \%$ significance level.

The WPC tensile and flexural properties increase gradually with increasing particle size from S1 to L1 and decrease with increasing particle size to L2 (Table 4, Figs. 2, 3,4 , and 5). Values of these properties for the WPC with L2 particles are greater than those for the WPC with S2 particles. The tensile modulus and strength of WPCs with larger (L1 and L2) particles are on average 12\% and 11\% greater, respectively, than those of WPCs with smaller (S1 and S2) particles. The relative difference between the tensile properties of WPCs with larger and smaller particles does not depend on specimen cross-section size.

The flexural modulus and strength of WPCs with larger particles are on average greater by $11 \%$ and $18 \%$, respectively, than those of WPCs with smaller particles. For the flexural modulus the relative difference between values of WPC with larger and smaller particles was greatest when this modulus was determined using specimens of

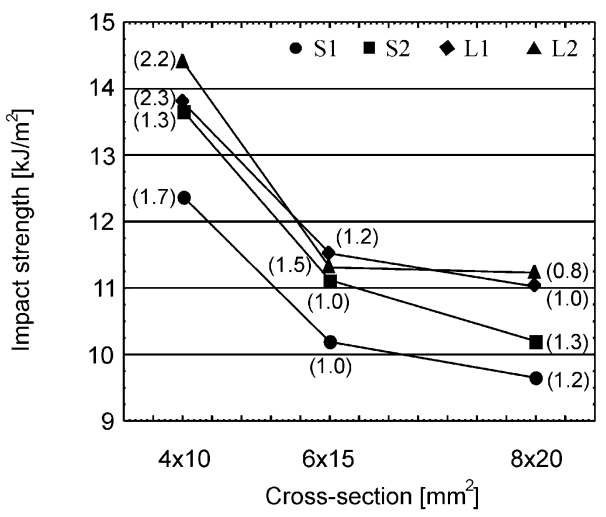

Fig. 6 Effect of specimen cross-section size on impact strength of WPC with different sizes of wood particles (standard deviations in parentheses)

Abb. 6 Einfluss der Querschnittsgröße der Prüfkörper und der Holzspangröße auf die Schlagfestigkeit von WPCs (Standardabweichung in Klammern)

Table 3 Two-way ANOVA test on the effects of particle size and cross-section size on WPC mechanical properties ( $p$-values)

Tab. 3 Zwei-Faktoren-ANOVA zur Bestimmung der Einflüsse von Spangröße und Querschnittsgröße auf die mechanischen Eigenschaften von WPCs $(p$-Werte)

\begin{tabular}{|c|c|c|c|c|c|}
\hline Variable & $\begin{array}{l}\text { Tensile } \\
\text { modulus }\end{array}$ & $\begin{array}{l}\text { Tensile } \\
\text { strength }\end{array}$ & $\begin{array}{l}\text { Flexural } \\
\text { modulus }\end{array}$ & $\begin{array}{l}\text { Flexural } \\
\text { strength }\end{array}$ & $\begin{array}{l}\text { Impact } \\
\text { strength }\end{array}$ \\
\hline Wood particle size & $<0.0001^{*}$ & $<0.0001^{*}$ & $<0.0001^{*}$ & $<0.0001^{*}$ & $0.0002^{*}$ \\
\hline Cross-section size & $<0.0001^{*}$ & $<0.0001^{*}$ & $0.0147^{*}$ & $<0.0001^{*}$ & $<0.0001^{*}$ \\
\hline $\begin{array}{l}\text { Wood particle size } \times \\
\text { cross-section size }\end{array}$ & $0.9883^{\mathrm{ns}}$ & $0.6005^{\mathrm{ns}}$ & $0.3388^{\mathrm{ns}}$ & $0.0388^{*}$ & $0.9120^{\mathrm{ns}}$ \\
\hline
\end{tabular}

\footnotetext{
* Denotes significance at 0.01
}

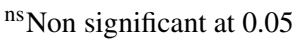


Table 4 Effect of wood particle size on WPC mechanical properties

Tab. 4 Einfluss der Größe der Holzspäne auf die mechanischen Eigenschaften von WPCs

\begin{tabular}{|c|c|c|c|c|c|}
\hline $\begin{array}{l}\text { Wood } \\
\text { particle } \\
\text { size }\end{array}$ & $\begin{array}{l}\text { Tensile } \\
\text { modulus } \\
(\mathrm{MPa})\end{array}$ & $\begin{array}{l}\text { Tensile } \\
\text { strength } \\
(\mathrm{MPa})\end{array}$ & $\begin{array}{l}\text { Flexural } \\
\text { modulus } \\
(\mathrm{MPa})\end{array}$ & $\begin{array}{l}\text { Flexural } \\
\text { strength } \\
(\mathrm{MPa})\end{array}$ & $\begin{array}{l}\text { Impact } \\
\text { strength } \\
\left(\mathrm{kJ} / \mathrm{m}^{2}\right)\end{array}$ \\
\hline S1 & $5290^{\mathrm{a}}$ & $35.2^{\mathrm{a}}$ & $4930^{\mathrm{a}}$ & $58.5^{\mathrm{a}}$ & $10.6^{\mathrm{a}}$ \\
\hline S2 & $5470^{\mathrm{ab}}$ & $37.0^{\mathrm{a}}$ & $5110^{\mathrm{ab}}$ & $63.3^{\mathrm{a}}$ & $11.7^{\mathrm{b}}$ \\
\hline L1 & $6210^{c}$ & $42.2^{\mathrm{b}}$ & $5720^{c}$ & $74.4^{\mathrm{b}}$ & $12.1^{\mathrm{b}}$ \\
\hline L2 & $5850^{\mathrm{bc}}$ & $38.3^{\mathrm{a}}$ & $5480^{\mathrm{bc}}$ & $69.3^{\mathrm{b}}$ & $12.3^{\mathrm{b}}$ \\
\hline
\end{tabular}

Mean values with the same letter for given property are not significantly different at the $5 \%$ significance level

$4 \times 10 \mathrm{~mm}^{2}$ cross-section. For flexural strength this difference was almost the same as when it was derived from testing the specimens of different cross-section size.

Regarding the impact strength, the composite made of the smallest particles showed the lowest value (Fig. 6). The other three groups had a higher score, and showed no significant difference (Table 4). The impact strength of WPCs with larger particles is on average 9\% greater than that of WPCs with smaller particles. The relative difference between the impact strength of WPCs with larger and smaller particles is greatest in determining this strength using specimens of $8 \times 20 \mathrm{~mm}^{2}$ cross-section.

The increase in the mechanical properties of tested WPCs with increasing wood particle size is a result of particle geometry. According to the mechanics of fibre-reinforced composite materials, one important factor affecting their mechanical properties is fibre aspect ratio defined as fibre length-to-thickness ratio. Fibres with a higher aspect ratio enhance stress transfer from the polymer matrix to the fibres and finally improve the composite mechanical properties. Values of this ratio for wood particles used in the study were 20.2 and 21.4 for L1 and L2 particles, respectively, and 14.9 and 16.3 for S1 and S2 particles, respectively (Table 2). Improving the WPC mechanical properties by particles with a higher aspect ratio was also observed for woodPP (Zaini et al. 1996; Stark and Rowlands 2003) and woodHDPE (Migneault et al. 2008, 2009) composites.

The tensile and flexural properties of tested WPCs with L2 particles are smaller than those of WPCs with L1 particles. The relative decreases are on average $7 \%$ and $5 \%$ for the tensile and flexural properties, respectively. These increases are probably due to the fact that too-large particles were breaking during the processing.

\subsection{Effect of cross-section size}

The effect of specimen cross-section size on WPC mechanical properties is presented in Figs. 2-6. In general, the properties derived from specimens with greater cross-section have lower values. Tensile, flexural and impact properties decrease gradually when cross-section size increases from $4 \times 10$ to $8 \times 20 \mathrm{~mm}^{2}$. Only for the WPC with S1 particles is the flexural modulus derived from the specimens of $6 \times 15 \mathrm{~mm}^{2}$ cross-section slightly greater than that determined using the specimens of $4 \times 10 \mathrm{~mm}^{2}$ cross-section.

WPC tensile modulus and strength derived from the specimens of $8 \times 20 \mathrm{~mm}^{2}$ cross-section are on average $11 \%$ and $17 \%$ smaller than those derived from the specimens of $4 \times 10 \mathrm{~mm}^{2}$ cross-section. The decrease in the tensile modulus is almost the same for WPCs with different wood particle size. The decrease in the tensile strength is greatest for the WPC with L1 particles.

WPC flexural modulus and strength derived from the specimens of $8 \times 20 \mathrm{~mm}^{2}$ cross-section are on average $6 \%$ and $16 \%$ smaller than those derived from the specimens of $4 \times 10 \mathrm{~mm}^{2}$ cross-section. The decrease in the flexural modulus is greater for WPCs with larger wood particles. The decrease in the flexural strength for WPCs with S2 and L1 particles is greater than that for WPCs with S1 and L2 particles.

The increase in specimen cross-section size results in a considerable decrease in WPC impact strength. This strength derived from the specimens of $8 \times 20 \mathrm{~mm}^{2}$ crosssection is on average $22 \%$ smaller than that derived from the specimens of $4 \times 10 \mathrm{~mm}^{2}$ cross-section. The decrease in this strength does not depend on wood particle size.

Standard deviations in the study results are affected by specimen cross-section size. In general they are lower for the results derived from testing specimens with larger crosssection. The decrease in standard deviations with increasing cross-section size is greater for WPCs with larger particle size. Standard deviations are also affected by wood particle size. They are generally higher when the particles are larger. Their increase with increasing particle size is highest for the results derived from specimens with the smallest cross-section. Summing up, the larger the cross-section size and the smaller the particle size, the lower the standard deviation. So, it is preferable to use specimens with a crosssection larger than a standard cross-section of $4 \times 10 \mathrm{~mm}^{2}$ to determine the mechanical properties of WPCs with larger particles. 


\section{Conclusions}

Industrial wood particles used for manufacturing three-layer particleboards can be a good raw material to make composites with PVC by an injection moulding method. These WPCs have good mechanical properties, which depend on particle size and the cross-section area of injection moulded pieces. The large-sized particles, used for manufacturing a core particleboard layer, provide better WPC properties than the small-sized particles used for manufacturing face particleboard layers. This is a result of the greater aspect ratio of larger wood particles. The mechanical properties derived from testing specimens with a larger cross-section area are in general lower, but show a lower standard deviation.

Acknowledgements This work was supported by grant N508 011 32/0844 from the Polish Ministry of Science and Higher Education. The authors would like to thank Kronospan Szczecinek Sp. z o.o. for providing wood material for this study.

Open Access This article is distributed under the terms of the Creative Commons Attribution Noncommercial License which permits any noncommercial use, distribution, and reproduction in any medium, provided the original author(s) and source are credited.

\section{References}

Bledzki AK, Gassan J, Theis S (1998) Wood-filled thermoplastic composites. Mech Compos Mater 34:563-568

Bledzki AK, Faruk O (2003) Wood fibre reinforced polypropylene composites: effect of fibre geometry and coupling agent on physico-mechanical properties. Appl Compos Mater 10:365-379

Bouafif H, Koubaa A, Perre P, Cloutier A (2009) Effects of fiber characteristics on the physical and mechanical properties of wood plastic composites. Compos Part A 40:975-1981

Chen HC, Chen TY, Hsu CH (2006) Effects of wood particle size and mixing ratios of HDPE on the properties of the composites. Holz Roh- Werkst 64:172-177

Cheng Q, Wang S, Rials TG, Kit KM, Hansen M (2009) Fabrication optimization of polypropylene composites reinforced with steamexploded wood flour by wet process. Eur J Wood Prod 67:449455

Cui Y, Lee S, Noruziaan B, Cheung M, Tao J (2008) Fabrication and interfacial modification of wood/recycled plastic composite materials. Compos Part A 39:655-661
Gozdecki C, Kociszewski M, Zajchowski S (2006) Use of particles from the particleboard manufacturing for the polypropylene filling. Ann Wars Univ Life Sci SGGW For Wood Technol 58:326329

Khalil HPSA, Shahnaz SBS, Ratnam MM, Ahmad F, Fuaad NAN (2006) Recycle polypropylene (RPP) wood saw dust (WSD) composites-Part 1: The effect of different filler size and filler loading on mechanical and water absorption properties. J Reinf Plast Compos 25:1291-1303

Kumari R, Ito H, Takatani M, Uchiyama M, Okamoto T (2007) Fundamental studies on wood/cellulose-plastic composites: effects of composition and cellulose dimension on the properties of cellulose/PP composite. J Wood Sci 53:470-480

Lee BJ, McDonald AG, James B (2001) Influence of fiber length on the mechanical properties of wood-fiber/polypropylene prepreg sheets. Mater Res Innov 4:97-103

Migneault S, Koubaa A, Erchiqui F, Chaala A, Englund K, Krause C, Wolcott M (2008) Effect of fiber length on processing and properties of extruded wood-fiber/HDPE composites. J Appl Polym Sci 110:1085-1092

Migneault S, Koubaa A, Erchiqui F, Chaala A, Englund K, Wolcott M (2009) Effects of processing method and fiber size on the structure and properties of wood-plastic composites. Compos Part A 40:80-85

Pan MZ, Zhou DG, Bousmina M, Zhang SY (2009) Effects of wheat straw fiber content and characteristics, and coupling agent concentration on the mechanical properties of wheat straw fiberpolypropylene composites. J Appl Polym Sci 113:1000-1007

Salemane MG, Luyt AS (2006) Thermal and mechanical properties of polypropylene-wood powder composites. J Appl Polym Sci 100:4173-4180

Stark NM, Rowlands RE (2003) Effects of wood fiber characteristics on mechanical properties of wood/polypropylene composites. Wood Fiber Sci 35(2):167-174

Takatani M, Ito H, Ohsugi S, Kitayama T, Saegusa M, Kawai S, Okamoto T (2000) Effect of lignocellulosic materials on the properties of thermoplastic polymer/wood composites. Holzforschung 54:197-200

Wilczyński A, Kociszewski M, Gozdecki C, Zajchowski S (2008) The effect of wood particle size on the properties of PP/wood composite made by injection molding method. In: The 7th Global WPC and Natural Fibre Composites Congress and Exhibition, Kassel, June 18-19, 2008, pp 6/1-16/5

Xu Y, Wu Q, Lei Y, Yao F, Zhang Q (2008) Natural fiber reinforced poly(vinyl chloride) composites: Effect of fiber type and impact modifier. J Polym Env 16:250-257

Zaini MJ, Fuad MYA, Ismail Z, Mansor MS, Mustafah J (1996) The effect of filler content and size on the mechanical properties of polypropylene/oil palm wood flour composites. Polym Int 49:5155 